Перерва П.Г.

доктор економ. наук, професор

Ткачова Н.П.

канд.екон.наук, доцент

Національний технічний університет «ХПI»

\title{
БЕНЧМАРКІНГ КОНКУРЕНТНИХ ПЕРЕВАГ
}

\author{
БЕНЧМАРКИНГ КОНКУРЕНТНЫХ ПРЕИМУЩЕСТВ
}

\section{BENCHMARKING COMPETITIVE ADVANTAGES}

У статті запропоновані методичні рекомендації і науково-практичні пропозиції з формування $i$ очінювання конкурентних переваг машинобудівних підприємств 3 використанням конщепиії бенчмаркінгу. Розроблено пропозиції по формуванню конкурентних переваг з використанням двох нерозривно пов'язаних напрямків: покращення показників ринкової діяльності підприємства та пряме або відносне зменшення результатів використання основних конкурентних переваг ринкових суперників підприємства. Запропоновано ввести в науковий обіг новий вид бенчмаркінгу конкурентно-синергетичний бенчмаркінг, використання якого передбачає отримання результатів для покращення ринкових позиџій підприємства та його продукції. Назва цьвого виду бенчмаркінгу зумовлена тим, щзо його проведення направлене не тільки на отримання нових або посилення існуючих конкурентних переваг підприємства, а $i$ на результативне проведення цьього виду бенчмаркінгу, щуо передбачає наявність синергетичного ефекту.

Ключові слова: бенчмаркінг, конкурентні переваги, синергетичний ефект

В статье обоснованы теоретические основы, методические рекомендации и научно-практические предложения по формированию и оценке конкурентных преимуществ машиностроительных предприятий $c$ использованием концепции бенчмаркинга. Разработаны предложения по формированию конкурентных преимуществ с использованием двух неразрывно связанных направлений: улучшение показателей рыночной деятельности предприятия и прямое или относительное уменьшение результатов использования основных конкурентных преимуществ рыночных соперников данного предприятия. Предложено ввести в научный оборот новый вид бенчмаркинга конкурентно-синергетический бенчмаркинг, использование которого предполагает получение результатов для улучшения рыночных позиций предприятия и его продукции. Название этого вида бенчмаркинга обусловлена тем, что его проведение направлено не только на получение новых или усиления существующих конкурентных преимуществ предприятия, но и на результативное проведение этого вида бенчмаркинга, что предполагает наличие синергетического эффекта.

Ключевые слова: бенчмаркинг, конкурентные преимущества, синергетический эффект

The article substantiates the theoretical bases, methodological recommendations and practical proposals for the formation and evaluation of competitive advantages of machine- 
building enterprises using the concept of benchmarking. Proposals for the management of competitive advantages in two inextricably linked ways: improvement in market activity of the company and the direct or relative decrease in the results of the use of the main competitive advantages of the market rivals of this company. Proposed to introduce into scientific circulation a new concept of benchmarking is competitive and synergetic benchmarking, which involves obtaining results to improve the market position of the company and its products. The name of this type of benchmarking is due to the fact that it is not only aimed at acquiring new or enhancing existing competitive advantages of the enterprise, but also effectively lead this form of benchmarking that involves the presence of a synergistic effect.

Keywords: benchmarking, competitive advantage, synergy effect

Вступ. В умовах посилення конкуренції на світовому та вітчизняному ринках промислової продукції проблема створення та використання конкурентних переваг є однією 3 найбільш актуальних [1]. Вирішення цієї проблеми нагально потребує всебічного аналізу проблем, пов'язаних 3 формуванням нових та посиленням існуючих конкурентних переваг, підвищенням рівня конкурентоспроможності машинобудівної продукції. Від рівня конкурентоспроможності продукції машинобудування, яка $є$ базою науково-технічного прогресу, залежить конкурентоспроможність всієї національної економіки $[2,3]$. Проблема формування та об'єктивної оцінки конкурентних переваг продукції машинобудівних підприємств $є$ ключовою у ряді основних напрямків посилення економічної безпеки держави. Уміння запропонувати потенційному споживачу те, що потрібно, домогтися, щоб споживач віддав перевагу саме цьому товару, за рахунок постійного поліпшення його споживчих властивостей створювати нові модифікації виробів, передбачаючи майбутні ринкові можливості галузі - ці задачі сьогодні є надзвичайно важливими та актуальними $[4,5]$.

Питання формування та оцінки конкурентних переваг машинобудівних підприємств досліджували у своїх роботах вітчизняні та зарубіжні науковці, зокрема: Г.Л. Азоєв [1], Ю.Б. Іванов [3], П.Г. Перерва [6, 7], І.П. Данилов [8], I.Н. Іванов [9], В.Н. Островская [10], О.В. Жегус [11], П. Терри [12], Р.А. Фатхутдинов [13] та ін. Особлива увага в цих дослідженнях приділяється питанням показникам якості конкретного товару, на основі яких і будуються показники його конкурентоспроможності та формуються конкурентні переваги підприємства на цільовому ринку.

Разом 3 тим, зарубіжна практика свідчить про наявність серед сучасних методів підвищення конкурентоспроможності досить ефективного інструменту менеджменту під назвою бенчмаркінг. Ця економічна категорія детально розглядалася в наукових працях Е. Білокоровіна [14], І.В. Гладенко[15], А. Еркова [16], П.Г. Перерви [17, 18], Ж.В. Горностаевої [19], О.П. Косенко [20], Б.Л. Кузнецова [21], В.Л. Товажнянського [22], Е.А. Михайлової [23] та ін. Проведення бенчмаркінгу конкурентних переваг підприємства, як свідчать попередні дослідження авторів [24, 25, 27] та 
Д.В. Маслова [26], по-перше, дозволяє підвищити рівень конкурентоспроможності підприємства; по-друге, дає можливість отримання додаткового синергетичного ефекту за рахунок спільної дії різних конкурентних переваг (як наявних, так i набутих, завдяки процесу бенчмаркінгу). Теоретична важливість зазначених завдань, їх практична значущість для ефективної діяльності підприємств, організацій обумовили вибір теми статті та окреслили коло питань, які в ній розглядаються.

Постановка завдання. Метою проведеного дослідження є обгрунтування теоретичних основ, методичних рекомендацій i науково-практичних пропозицій 3 формування i оцінювання конкурентних переваг машинобудівних підприємств з використанням концепції бенчмаркінгу.

Методологія. Теоретичну і методологічну основу дослідження складають фундаментальні положення сучасної економічної теорії, наукові праці i методичні розробки провідних вітчизняних та зарубіжних вчених в сфері управління конкурентоспроможністю підприємства та концептуальних положень бенчмаркінгу.

Результати дослідження. Управління конкурентними перевагами промислового підприємства повинна базуватися на упередженні конкурентної відповіді своїх ринкових суперників, на детальному вивченні їх прогресивного досвіду в ринковій стратегії, на розробці такого сценарію створення конкурентних переваг який би передбачав розвиток подій в двох нерозривно пов'язаних напрямках:

1. Покращення показників ринкової діяльності підприємства в ланцюжку інновації-виробництво-товар-збут-споживання-послуги та зростання узагальнюючого показника виробничо-підприємницької діяльності підприємства (обсяги збуту, розмір отриманого прибутку, розширення ринку i т.п.).

2. Пряме або відносне зменшення результатів використання основних конкурентних переваг ринкових суперників підприємства.

Аналітична оцінка позитивних результатів першого напрямку не визиває особливих складнощів. Другий напрямок, на наш погляд, складніше піддається аналітичній формалізації в зв'язку з багатоваріантністю його форм. Авторами пропонується використовувати наступні основні види (форми) аналітично-перевірочної оцінки реалізації результатів цього напрямку:

а) пряме зменшення індивідуального рівня конкурентоспроможності ринкових суперників підприємства як результат проведення бенчмаркінгу, що може бути відтворено наступною аналітичною залежністю:

$$
P_{i j}{ }^{l}<P_{i j}{ }^{0},
$$

де $P_{i j}{ }^{0}, P_{i j}{ }^{1}-$ рівень конкурентоспроможності $j$-го конкурента (бенчмаркінгпартнера) по відношенню до $i$-го підприємства, яке проводить вибрану 
стратегію бенчмаркінгу, відповідно, до і після проведення бенчмаркінгових заходів.

б) пряме зменшення загального (галузевого) рівня конкурентоспроможності ринкових суперників підприємства як результат проведення бенчмаркінгу (при цьому галузевий рівень конкурентоспроможності $i$-го підприємства не погіршився):

$$
\begin{gathered}
P_{j}{ }^{l}<P_{j}^{0} ; \\
I_{i}^{1} \geq I_{i}^{0},
\end{gathered}
$$

де $P_{j}^{0}, P_{j}^{l}-$ загальний (галузевий) рівень конкурентоспроможності $j$-го конкурента (партнера по бенчмаркінгу), відповідно, до і після проведення бенчмаркінгових заходів $i$-м підприємством; $I_{i}^{1}, I_{i}^{0}$ - загальний (галузевий) рівень конкурентоспроможності $i$-го підприємства, відповідно, до і після проведення бенчмаркінгових заходів.

в) відносне зменшення індивідуального рівня конкурентоспроможності ринкових суперників підприємства по результатам проведення бенчмаркінгу характеризується системою аналітичних залежностей:

$$
P_{i j}{ }^{l}>P_{i j}{ }^{0} ; ; \quad I_{i j}{ }^{l}>I_{i j}{ }^{0} ; \quad\left(I_{i j}{ }^{l} / P_{i j}{ }^{l}\right)>\left(I_{i j}{ }^{0} / P_{i j}{ }^{0}\right) .
$$

Наведені нами залежності відтворюють такий стан конкурентних відносин бізнес-суперників підприємства, коли в конкурента покращуються ринкові позиції, але в меншому ступені відносно підприємства, що проводило бенчмаркінгові заходи.

г) відносне зменшення загального (галузевого) рівня конкурентоспроможності ринкових суперників підприємства як результат проведення бенчмаркінгу:

$$
P_{j}^{l}>P_{j}^{0} ; \quad I_{i}^{1}>I_{i}^{0} ;\left(I_{i}^{l} / P_{j}^{l}\right)>\left(I_{i}^{0} / P_{j}^{0}\right) .
$$

Множина можливих станів даного підприємства та його ринкового суперника після проведення бенчмаркінгу з метою формування або посилення його конкурентних переваг представлена нами в таблиці.

\begin{tabular}{|c|c|c|c|}
\hline $\begin{array}{l}\text { Варіанти зміни рівня конкурентоспро- } \\
\text { можності за результатами бенчмаркінгу }\end{array}$ & $\begin{array}{c}\text { Аналітично-перевіро } \\
\text { оцінка }\end{array}$ & $\begin{array}{l}\text { Тенд- } \\
\text { енція }\end{array}$ & \\
\hline Прям & $\begin{aligned} P_{i j}{ }^{l} & <P_{i j}{ }^{0}, \\
I_{i j} & >I_{i j}{ }^{1}\end{aligned}$ & $\begin{array}{l}\text { Пози- } \\
\text { тивна }\end{array}$ & \multirow{3}{*}{ 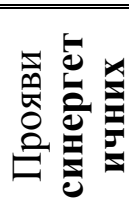 } \\
\hline $\begin{array}{l}\text { Відносне зменшення індивідуального } \\
\text { рівня конкурентоспроможності конкурента }\end{array}$ & 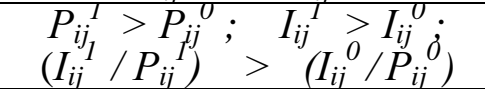 & & \\
\hline Пряме зменшення загального (галузевого) & $P_{j}^{1}<P_{j}^{J}$ & Пози- & \\
\hline
\end{tabular}

Таблиця

Множина результатів проведення бенчмаркінгу по відношенню до конкуруючого підприємства 


\begin{tabular}{|c|c|c|c|}
\hline $\begin{array}{l}\text { рівня конкурентоспроможності } \\
\text { конкурента }\end{array}$ & $T_{i}$ & "тивна & \\
\hline $\begin{array}{l}\text { Відносне зменшення загального } \\
\text { (галузевого) рівня } \\
\text { конкурентоспроможності конкурента }\end{array}$ & 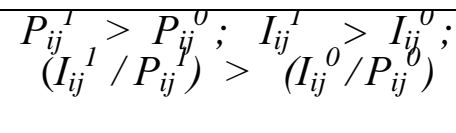 & $\begin{array}{l}\text { Пози- } \\
\text { тивна }\end{array}$ & \\
\hline $\begin{array}{l}\text { Незмінність позицій конкурента } \\
\text { підприємства, що проводить бенчмаркінг }\end{array}$ & 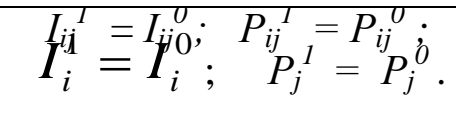 & \multicolumn{2}{|c|}{$\begin{array}{c}\text { Без } \\
\text { помітних } \\
\text { езультатів }\end{array}$} \\
\hline $\begin{array}{l}\text { Пряме збільшення індивідуального рівня } \\
\text { конкурентоспроможності конкурента }\end{array}$ & $\begin{aligned} & P_{i j}{ }^{I}> \\
& I_{i j}{ }^{l}<I_{i j}{ }^{0} \\
&\end{aligned}$ & $\begin{array}{l}\text { Нега- } \\
\text { тивна }\end{array}$ & \multirow{4}{*}{ 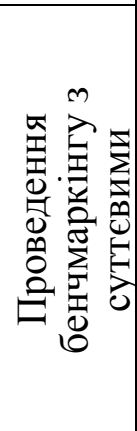 } \\
\hline $\begin{array}{l}\text { Відносне збільшення індивідуального } \\
\text { рівня конкурентоспроможності конкурента }\end{array}$ & $\begin{array}{l}P_{i j^{\prime}}>P_{i j}{ }^{j} ; \quad I_{i j}>I_{i j}{ }^{0} \\
\left(I_{i j} / P_{i j}{ }^{l}\right)<\left(I_{i j} / P_{i j}\right)\end{array}$ & $\begin{array}{l}\text { Нега- } \\
\text { тивна }\end{array}$ & \\
\hline $\begin{array}{l}\text { Пряме збільшення загального (галузевого) } \\
\text { рівня конкурентоспроможності } \\
\text { конкурента }\end{array}$ & $P_{j 1} \geq P_{J}^{j}$ & $\begin{array}{l}\text { Нега- } \\
\text { тивна }\end{array}$ & \\
\hline $\begin{array}{l}\text { Відносне збільшення загального } \\
\text { (галузевого) рівня } \\
\text { конкурентоспроможності конкурента }\end{array}$ & 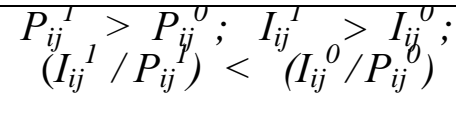 & $\begin{array}{l}\text { Нега- } \\
\text { тивна }\end{array}$ & \\
\hline
\end{tabular}

1. Ефективним для підприємства $\epsilon$ здійснення бенчмаркінгу 3 використанням перших чотирьох варіантів (таблиця), так як в цих випадках підприємство отримує певні конкурентні переваги перед своїм конкурентом за результатами проведення бенчмаркінгу.

2. В ефективних для підприємства варіантах проведення бенчмаркінгу (перші чотири варіанти в таблиці), на наш погляд, спостерігається наявність синергетичних ефектів.

3. В негативних для підприємства варіантах проведення бенчмаркінгу (останні чотири варіанти в таблиці) також може мати місце наявність синергетичних ефектів. Такий висновок пояснюється тим, що в іншому разі погіршення справ на підприємстві могло бути ще більшим, а проведення бенчмаркінгу допомогло уникнути такого стану.

На наявність синергії при проведенні бенчмаркінгу вже вказували деякі дослідники. В цьому плані слід вказати дослідження, проведені Б.Л. Кузнецовим., М.М. Шарамко та В.М. Островською [21, 10]. Разом 3 тим, доводячи наявність синергії при проведенні бенчмаркінгу Б.Л. Кузнецов та M.М. Шарамко не пов'язують цей процес 3 можливістю створення конкурентних переваг та підвищенням рівня конкурентоспроможності [21]. В дослідженнях В.М. Островської [10], навпаки, доводиться важливість бенчмаркінгових процесів для підвищення конкурентоспроможності, але тільки контурно вказується на можливість наявності ефектів синергії.

Висновок авторів про наявність синергетичних ефектів при проведенні бенчмаркінгу конкурентних переваг по відношенню до підприємств машинобудівної галузі промисловості, на нашу думку, обгрунтовується наступними посиланнями. По-перше, при проведенні звичайних (не бенчмаркінгових) заходів на підприємства в напрямку підвищення

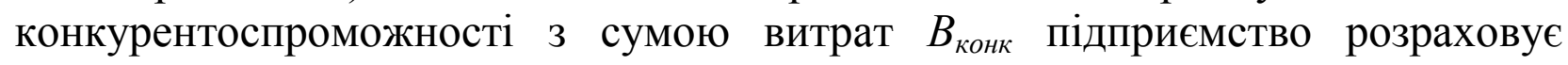


отримати додатково збільшення рівня конкурентоспроможності по відношенню до свого конкурента (або в цілому до галузі) - $\Delta I_{i j}$, тобто:

$$
\Delta I_{i j}=f\left(B_{\text {конк }}\right) \text {. }
$$

При проведенні бенчмаркінгу в його позитивних варіантах (таблиця), підприємство при тих же витратах на підвищення конкурентоспроможності отримує дещо більший результат, який тепер має вже дві складові:

а) безпосереднє набуття або покращення рівня конкурентної (конкурентних) переваги (переваг), що відповідає витратам $B_{\text {конк; }}$;

б) послаблення позиції конкурента на величну $\Delta P_{i j}$ за рахунок більш активного використання його конкурентної (конкурентних) переваги (переваг) даним підприємством в результаті проведення бенчмаркінгу, згідно концептуальних положень бенчмаркінгової теорії.

При цьому в результаті проведення бенчмаркінгу ми отримуємо синергетичний ефект [24, 27] в вигляді більшого збільшення рівня конкурентоспроможності по відношенню до партнера по бенчмаркінгу, тобто

$\Delta P_{i j}$, що може бути розцінено як наявність синергетичного ефекту:

$$
\Delta I_{i j}{ }^{\sigma}=f\left(B_{\text {конк }}\right)=\left(\Delta I_{i j}+\Delta P_{i j}\right)>\Delta I_{i j} .
$$

Слід звернути особливу увагу на те, що синергетичні ефекти, що проявлятися в інтегральному показнику конкурентоспроможності, на наш погляд, можуть стосуватися як безпосередньо товару, так і процесів, що проходять на підприємстві при його виробництві (процесів бенчмаркінг), в галузі при стратегічному плануванні розвитку підприємства (стратегічний бенчмаркінг), так і в міжгалузевому просторі на внутрішньому і зовнішньому ринках (глобальний бенчмаркінг).

Виходячи з вищевикладеного, пропонуємо ввести в науковий обіг новий вид бенчмаркінгу - конкурентно-синергетичний бенчмаркінг, використання якого передбачає отримання результатів по одному з перших чотирьох варіантів, представлених в таблиці. Назва цього виду бенчмаркінгу [27] зумовлена тим, що його проведення дозволяє не тільки отримати нові або посилити існуючі конкурентні переваги підприємства, a i результативно провести цей вид бенчмаркінгу, що передбачає наявність синергетичного ефекту. 3 урахуванням останніх пропозицій, етапи (хвилі розвитку), які бенчмаркінг пройшов за термін від свого народження до теперішнього часу приймають вигляд, який представлено нами на рисунку. 


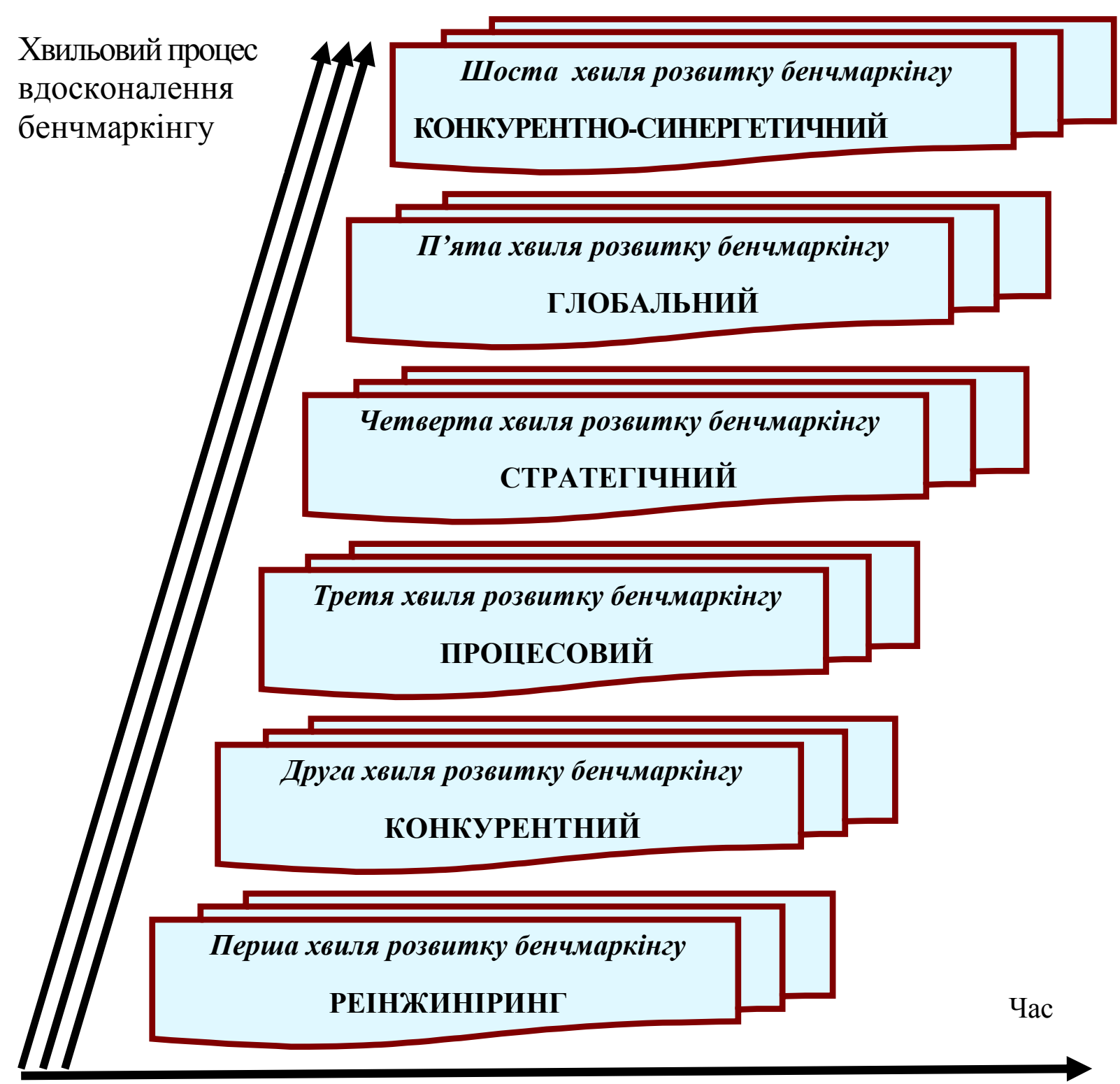

Рисунок. Динаміка хвильового розвитку бенчмаркінгу з урахування пропозицій авторів

Висновки. Інституційне оформлення конкурентно-синергетичного бенчмаркінгу як напряму розвитку існуючих (традиційних) концепцій бенчмаркінгу пропонується здійснити за допомогою виділення його в новий метод дослідження конкурентів машинобудівного підприємства, який заснований на співпраці та взаємодії 3 іншими суб'єктами ринку 3 метою взаємовигідного партнерського обміну інформацією з конкурентами, бізнеспартнерами, дочірніми підприємствами, внутрішніми структурними підрозділами і т.ін. для вдосконалення окремих бізнес-процесів і підвищення конкурентоспроможності бізнесу в цілому. 


\section{Література:}

1. Азоев Г.Л. Конкурентные преимущества фирмы / Г.Л. Азоев, А.П. Челенков / Гос. ун-т управления, Нац. фонд подготовки кадров. - М. : ОАО «Тип «НОВОСТИ», 2000. - 256 c.

2. Перерва, П.Г. Організація та управління інноваційною діяльністю: підруч. / П.Г.Перерва, С.А.Мехович, М. І. Погорєлов. -Харків: НТУ "ХПІ", 2008. - 1025 с.

3. Іванов Ю.Б. Конкурентні переваги підприємства: оцінка, формування та розвиток: монографія / Ю.Б. Іванов, П.А. Орлов, О.Ю. Іванова. - Х. : ІНЖЕК, 2008. - 352 с.

4. Перерва П.Г. Экономика и управление инновационной деятельностью: учебник / Под ред. проф. Перервы П.Г., проф. Вороновского Г.К., проф. Меховича С.А., проф. Погорелова Н.И. - Харьков: НТУ «ХПИ», 2009. - 1203 с.

5. Грабченко А.И. Основы маркетинга высоких технологий : учебное пособие [Текст] / А.И. Грабченко, П.Г. Перерва, Р.Ф. Смоловик. - Х. : ХГПУ, 1999. - 242 с.

6. Перерва П. Г. Економіка і маркетинг виробничо-підприємницької діяльності: Навч. посібник / За ред. проф. Перерви П. Г., проф. Гаврись О. М., проф. Погорєлова М. І. Харків : НТУ «ХПІ», 2004. - 640 с.

7. Перерва П. Г. Економіка та організація інноваційної діяльності : підруч. / П. Г. Перерва; за ред. П. Г. Перерви, С. А. Меховича, М. І. Погорєлова. - Харків : НТУ «ХПІ», 2008. - $1080 \mathrm{c}$.

8. Данилов И.П. Бенчмаркинг - эффективный инструмент повышения конкурентоспособности / И.П. Данилов, С.Ю. Михайлова, Т.В. Данилова // Стандарты и качество. 2005. - №1. - С. 44.

9. Иванов И.Н. Конкурентный анализ. Бенчмаркинг / И.Н. Иванов, Д.Ю. Фукова // Экономический анализ: теория и практика. - 2009. - №22. - С. 53-55.

10. Островская В.Н. Конкурентно-интеграционный бенчмаркинг как инструмент эффективного взаимодействия российских предприятий розничной торговли в период кризиса: монография / В.Н. Островская. - М. : КноРус, 2009. - 368c.

11. Перерва П.Г. Науково-інноваційний потенціал України та сучасні проблеми його використання / П.Г. Перерва, О.В. Жегус. - [Електронний ресурс]. — Режим доступу: http://archive.nbuv.gov.ua/portal/Natural/vcpi/TPtEV/2011_26/statiya/Pererva.pdf

12. Пилчер Терри. Бенчмаркинг как средство повышения конкурентоспособности / Терри Пилчер // Европейское качество. - 2004. - №1. - С. 40-46.

13. Фатхутдинов Р.А. Менеджмент конкурентоспособности товара / Р.А. Фатхутдинов. - М. : АО «Бизнес-школа «Интел-Синтез», 1995. - 56c.

14. Белокоровин Э. Как использовать возможности бенчмаркинга в отечественных условиях / Э. Белокоровин, Д. Маслов // Управление компанией. - 2005. - № 1. - С. 10-16.

15. Перерва П.Г. Моніторинг інноваційної діяльності: інтерпретація результатів / П.Г. Перерва, І.В. Гладенко // Маркетинг і менеджмент інновацій. - Суми: 2010. - № 2. - С. $108-$ 116.

16. Ерков А. Бенчмаркинг - современное направление развития маркетинга [Електронний ресурс] / А. Ерков // Отраслевой портал «Логистика». - Режим доступу: http://www.logistics.ru/9/3/index.htm.

17. Перерва П.Г. Самомаркетинг менеджера и бизнесмена / П.Г.Перерва. - Ростов н / Д: Феникс, 2003. - 592 с. (Серия «Психология бизнеса»).

18. Перерва П.Г. Трансфер технологій : монографія / [П.Г.Перерва, Д.Коциски, Д.Сакай, М. Верешне Шомоши]. - Х. : Віровець А.П. «Апостроф», 2012. - 668 с. 
19. Горностаева Ж.В. Бенчмаркинг в сфере услуг: монография Ж.В. Горностаева [и др.]; ГОУ ВПО «Южно-Рос. гос. ун-т экономики и сервиса». - Шахты : ГОУ ВПО «ЮРГУЭС», 2009. - 97 с.

20. Перерва П.Г. Антикризові інструменти сталого розвитку підприємства: інноваційна, інвестиційна та маркетингова політика [Електронний ресурс] / П.Г. Перерва, А.В. Косенко, О.П. Косенко http://www.nbuv.gov.ua/portal/natural/vcpi/TPtEV/2012_25/statti/16Pererv.pdf.

21. Кузнецов Б.Л. Синергетический бенчмаркинг / Б.Л.Кузнецов, М.М.Шарамко. Набережные Челны : узд-во КамПИ, 2006. -135с.

22. Перерва П.Г. Антикризовий моніторинг фінансово-економічних показників роботи машинобудівного підприємства / П.Г.Перерва, В.Л.Товажнянський // Економіка розвитку. Х.: ХНЕУ. - 2010. - № 2 [54]. - С.46-50.

23. Михайлова Е.А. Бенчмаркинг/Е.А. Михайлова. - М. : Благовест-В, 2002. - 176 с.

24. Перерва П. Г. Синергетичний ефект бенчмаркінгу конкурентних переваг / П. Г. Перерва, Н.П.Ткачова // Маркетинг і менеджмент інновацій . - 2011. - № 4(1). - С. 55-66.

25. Перерва П. Г. Розвиток методів аналізу фактичного стану конкурентних переваг підприємства / П. Г. Перерва, Н. П. Ткачова // Економіка розвитку. - Харків : ХНЕУ, 2011. - № 4 (60). - С. 116-120.

26. Маслов Д.В. Особенности применения бенчмаркинга на малых и средних предприятиях / Д.В. Маслов, Э.А. Белокоровин // Методы менеджмента качества. 2004г. №8. - С.66.

27. Ткачова Н.П. Формування конкурентних переваг продукції машинобудівних підприємств на засадах бенчмаркінгу: Автореф. дис... канд. екон. наук: 08.00.04 / Національний технічний ун-т «ХПІ». — Х., 2012. - 22c. 